\title{
Bioprospecting and Drug Development, Parameters for a Rational Search and Validation of Biodiversity
}

Juan B*

Bioprospecting Development and Consulting, Bogotá, Colombia

\begin{abstract}
Bioprospecting describe the procedure of exploration, extraction, screening and trading of new products using biological diversity as source. Bioprospecting process is a multidisciplinary enterprise that involves various research actors and scientific subjects. Also a bioprospecting program investigates the indigenous understanding about practices and characteristics of medicinal plants and animals as well as the search for formerly unidentified compounds in natural sources that have never been used in folk medicine. The aim of this editorial is to give a rational approach for design a bioprospecting program for drug development, useful for to initiate a search on the primary screening of new drugs from biodiversity.
\end{abstract}

Keywords: Bioprospecting; Drug development; Biodiversity

\section{Introduction}

Natural products (NP) are defined as all substances produced by living organisms that include secondary metabolites defined as compounds produced by biological processes that are not necessary for primary or energy metabolism, but are important for ecological fitness. These molecules have been developed by the evolutionary pressure on biosynthetic pathways which results in a large and exuberant chemical diversity with potent biological activity [1]. Equally, due to secondary metabolites are involved in defense and signaling, are of pharmacological importance and a great starting points for obtention of new drugs with high impact on chemical biology and pharmaceutical industry [2,3]. NPs are obtained from biological diversity defined in Article 2 of the Convention on Biological Diversity as "The variability among living organisms from all sources including, inter alia, terrestrial, marine, and other aquatic ecosystems and the ecological complexes of which they are part; this includes diversity within species, between species and of ecosystems" [4].

The prospective study of biodiversity looking for applications in agriculture, industry and medicine; known as bioprospecting, is defined as the process of looking for in natural sources new promising genetic resources and bioactive compounds as well as organisms with biotechnological uses [5]. In this way, NPs have important contributions in drug discovery as acetylsalicylic acid (ASA) (painkiller derived from willow bark, Salix alba), reserpine (antihypertensive from Rauwolfia serpentina, known as Indian snake root), $d$-tubocurarine (muscle relaxant used in anesthesia from Chondrodendron tomentosum), artemisin (derived from Artemisia annua used as an anti-malarial agent) and vincristine and vinblastine (anti-cancer drugs derived from Catharanthus roseus) [5] .

Bioprospecting is constituted as scientific and economic activity with a high impact on sustainable development and poverty reduction as well as economic growth for developing countries. Because the establishment biodiversity based industries produce social appropriation of knowledge showing the benefits and applications of biodiversity [6]. Also, the revenue from royalties represented by the development of new medicines (have been estimated that a successful drug can generate $\$ 1$ billion per year) derived from natural sources contribute to the conservation of biodiversity in mega diverse countries as well as the protection of traditional medical knowledge [7].
Also, bioprospecting programs have been reinforced by the emergence of metabolomics as scientific discipline specialized in to measure the dynamic metabolic response of living systems to biological stimuli or genetic manipulation is an important tool in the new trends in drug discovery from NPs. In this way, metabolomics seeks an analytical description of secondary metabolites production focused in the following areas: quantification of metabolites, obtention of metabolic profiles of compounds related to different metabolic pathways, development of a metabolomic fingerprinting that classify the biological sample and correlation of metabolite production with a specific genomic sequence $[8,9]$.

Equally a rational bioprospecting program have to include new approaches that can improve the application of promising NPs in medicine, industry and agriculture, that is the case of nanotechnology which is an emerging and multidisciplinary field that integrate techniques and tools from biology, engineering, chemistry and medicine. In this order of ideas nanotechnology have been applied to design novel drug delivery systems (NDDS) for NPs, with the end of increase the bioavailability without adverse effects (increasing the therapeutic effect), as well as the treatment compliance and reducing the repeated administration $[10,11]$.

Finally, a successful bioprospecting program depends of the clarification of several parameters and their coherent combination (Table 1). A correct and functional construction of bioprospecting efforts in mega diverse countries must be the result of a multidisciplinary study in where the principal aim is the sustainable growth of the communities in the benefit of the ecosystems conservation and the public health impact of the developed products.

${ }^{*}$ Corresponding author: Juan B, Bioprospecting Development and Consulting, Bogotá, Colombia, E-mail: juangbueno@gmail.com

Received January 04, 2017; Accepted January 10, 2017; Published January 17 2017

Citation: Juan B (2017) Bioprospecting and Drug Development, Parameters for a Rational Search and Validation of Biodiversity. J Microb Biochem Technol 9: e128. doi:10.4172/1948-5948.1000e128

Copyright: (c) 2017 Juan B. This is an open-access article distributed under the terms of the Creative Commons Attribution License, which permits unrestricted use, distribution, and reproduction in any medium, provided the original author and source are credited. 
Citation: Juan B (2017) Bioprospecting and Drug Development, Parameters for a Rational Search and Validation of Biodiversity. J Microb Biochem Technol 9: e128. doi:10.4172/1948-5948.1000e128

Page 2 of 2

\begin{tabular}{|c|c|c|c|c|c|}
\hline $\begin{array}{l}\text { Bioprospecting } \\
\text { program }\end{array}$ & Global health issues & Sources & $\begin{array}{c}\text { Parameters of species } \\
\text { selection }\end{array}$ & $\begin{array}{l}\text { Complementary } \\
\text { approaches }\end{array}$ & $\begin{array}{l}\text { Products to obtain in a } \\
\text { bioprospecting program }\end{array}$ \\
\hline Terrestrial & Antimicrobial resistance & Plants & Ethnopharmacology & Metagenomics & Pharmaceuticals \\
\hline Freshwater origin & Cardiovascular diseases & Fungi & Chemotaxonomy & Protemics & Chemical scaffolds \\
\hline Marine & Cancer & Animals & Ecological chemistry & Metabolomics & Bioprocesses \\
\hline Polar regions & Malnutrition & Algae & Random search & Combinatorial chemistry & Formulations \\
\hline \multirow[t]{6}{*}{ Extreme environments } & Mental diseases & Insects & Bioassay-guided isolation & Medicinal chemistry & $\begin{array}{l}\text { Genetic modified } \\
\text { organisms }\end{array}$ \\
\hline & Pollution & Ciliates & & Organic synthesis & \\
\hline & $\begin{array}{l}\text { Emerging infectious } \\
\text { diseases }\end{array}$ & Bacteria & & & \\
\hline & & Archaea & & & \\
\hline & & Microbial endophytes & & & \\
\hline & & Marine organisms & & & \\
\hline
\end{tabular}

Table 1: Parameters for to be considered in a rational bioprospecting program.

\section{References}

1. Gostner JM, Wrulich OA, Jenny M, Fuchs D, Ueberall F (2012) An update on the strategies in multicomponent activity monitoring within the phytopharmaceutical field. BMC Complement Altern Med 12: 18.

2. Hong J (2011) Role of natural product diversity in chemical biology. Curr Opin Chem Biol 15: 350-354.

3. Jayaseelan KV, Moreno P, Truszkowski A, Ertl P, Steinbeck C (2012) Natura product-likeness score revisited: An open-source, open-data implementation. BMC Bioinformatics 13: 106.

4. Riccioli F, Fratini R, Boncinelli F, El Asmar T, El Asmar, et al. (2016) Spatia analysis of selected biodiversity features in protected areas: a case study in Tuscany region. Land Use Policy 57: 540-554.

5. Bhatia P, Chugh A (2015) Role of marine bioprospecting contracts in developing access and benefit sharing mechanism for marine traditional knowledge holders in the pharmaceutical industry. Global Ecology and Conservation 3: 176-187.
6. Paul S (2015) Trips and biotechnology vs. CBD and biodiversity: is it Bioprospecting or Bio-piracy of developing countries' traditional knowledge? International Journal of Physical and Social Sciences 5: 603-631.

7. Leary D (2008) Bipolar Disorder. Is Bioprospecting an Emerging Issue for the Arctic as well as for Antarctica? Review of European Community \& Internationa Environmental Law 17: 41-55.

8. Ulrich-Merzenich $\mathrm{G}$, Zeitler H, Jobst D, Panek D, Vetter H, et al. (2007) Application of the Omic technologies in phytomedicine. Phytomedicine 14: 70-82.

9. Forseth RR, Schroeder FC (2011) NMR-spectroscopic analysis of mixtures: from structure to function. Curr Opin Chem Biol 15: 38-47.

10. Ansari SH, Islam F, Sameem M (2012) Influence of nanotechnology on herbal drugs: A Review. J Adv Pharm Technol Res 3: 142-146.

11. Kumari A, Kumar V, Yadav SK (2012) Nanotechnology: A tool to enhance therapeutic values of natural plant products. Trends Med Res 7: 34-42. 